\title{
NAV And Risk: The Case Of REITs
}

\author{
William Brent, Howard University, USA \\ Lynne Kelly, Howard University, USA \\ Debby Lindsey, Howard University, USA \\ Russell M. Price, Howard University, USA
}

\begin{abstract}
A study is done on Net Asset Value (NAV) of equity REITs from 1993 to 2006. The value (growth) determination of REITs is investigated based on NAV per share as opposed to book value per share since the underlying value of the REITs' assets (NAV) drives the trading decision. The NAV to Market ratio (NM) is evaluated as a risk measure when used in a Fama-French and Carhart model setting. We find this measure contributes only $0.10 \%$ to the REIT risk premium.
\end{abstract}

Keywords: REITs; pricing models; NAV; real estate factors

\section{INTRODUCTION}

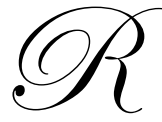
eal Estate Investment Trusts (hereafter referred to as REITs) are investment companies that engage in the ownership of real estate related assets. Equity REITs acquire income- producing properties for their respective portfolios. Mortgage REITs acquire mortgages of real property for their portfolios. In addition, there are "hybrid" REITs that engage in ownership of both types of assets. As a corporate entity, REITs issue shares that trade either publicly or privately; REITs have served as a vehicle for the average investor to have ownership interest in real estate.

REITs are required by law to distribute $90 \%$ of their net income to shareholders as dividends. This allows the REIT to have tax-exemption on the net income that is distributed as dividends. This provision also shields the investor from the "double taxation" issue. REITs have characteristics similar to closed-end funds (CEFs) where shares are bought or sold during the course of the trading period. REITs possess another similarity to closed-end funds; they are evaluated at two levels: share price and the Net Asset Value (NAV) of the underlying assets in the investment portfolio.

Generally, the share price of a REIT is determined by supply and demand. The NAV however is more prone to valuation methodology that is not directly observable. As a result, market share prices and NAV prices generally differ. If a REIT trades at a price greater than its NAV, then the REIT sells at a premium. If the REIT price is less than the NAV, then it sells at a discount.

The identification of risk factors in REITs is necessary to see if they can accurately predict returns. Chaudhry, Maheshwari and Webb (2004) use a dataset of REITs from 1994 to 2000 and find leverage, performance measures (EBIT scaled by book and market value) and earnings variability can predict REIT returns. Liang, McIntosh and Webb (1995) find evidence of market and interest rate risk among REITs from 1973 to 1989. Peterson and Hseih (1997) look at risk factors inherent in stocks and bonds to see if they can be applied to REITs. They study REIT performance from 1976 to 1992 and find risk premiums of equity REITs behave similar to the Fama-French (1993) factors (market, size, book to market) and risk premiums of mortgage REITs behave similar to Fama-French stock and two other bond factors (term and default). REITs are known to perform similar to small size stocks (market capitalization $<\$ 1$ billion). Since most equity REITs are small capitalization assets, there should be a risk factor available that more accurately represents an ability to predict returns.

NAV is the underlying measure of asset valuation. The level of discount would establish an NAV to market measure (hereafter referred as NM) that would better serve REITs than book to market (BM). As with mainstream assets, low NM is associated with value REITs, high NM with growth REITs. The HML measure for 
REITs (hereafter HMLNM) is evaluated by using it instead of HML in a Fama-French and Carhart model setting to see if this measure does a better job in predicting REIT returns. The HMLNM factor is added to the models in another effort to isolate a REIT factor in asset pricing. The three and four factor models are adjusted by using a REIT based market and size index.

The remainder of the study is organized as follows. A discussion of the methodology and construction of the discount (premium) and the HMLNM index occurs in the second section. The third section is used to discuss analysis results. An analysis of the effects of real estate related indices on the models appears in the fourth section. The fifth section is used to conclude the study.

\section{METHODOLOGY AND DATA}

\section{REIT Risk Factor Based On Net Asset Value (NAV)}

REITs are investment companies that specialize in holding income producing properties (equity REITs), mortgages of properties (mortgage REITs) or a mixture of both (hybrid REITs). Equity REITs, in particular, hold assets in their portfolios with an underlying value based on Net Asset Value that is normally different figure from its market capitalization. The ratio of market to NAV is typically used to determine discount which is predicated by the investor's perception of risk. It would stand to reason that the inverse of this relationship, NAV to market, could be considered as a risk factor. This factor would be of greater use in the REIT world than book to market since NAV is a more prevalent measure than book value. This factor can determine how it affects two of the most known asset pricing models, the three-factor model introduced by Fama and French (1993) and the four-factor model introduced by Carhart (1997):

$R_{i t}-R_{f t}=\alpha_{0 \mathrm{i}}+\beta_{\mathrm{i}}\left(R_{m t}-R_{f t}\right)+\mathrm{s}_{\mathrm{i}} S M B_{t}+\mathrm{h}_{\mathrm{i}} H M L_{t} ;$

where

$R_{i t}-R_{f t}=$ REIT risk premium;

$R_{i t}=$ Quarterly returns of REIT $i$ at time $t$;

$R_{f t}=$ Risk-free rate at time $t$;

$R_{m t}-R_{f t}=$ Market risk premium using the NYSE/AMEX/NASDAQ equal-weighted return as a market measure at time $t$;

$S M B_{t}=$ the "size factor" at time $t$;

$H M L_{t}=$ the "value factor" 2 at time $t$;

$R_{i t}-R_{f t}=\alpha_{0 \mathrm{i}}+\beta_{\mathrm{i}}\left(R_{m t}-R_{f t}\right)+\mathrm{s}_{\mathrm{i}} S M B_{t}+\mathrm{h}_{\mathrm{i}} H M L_{t}+\mathrm{m}_{\mathrm{i}} M O M_{t}$

where

$M O M_{t}=$ the "momentum factor" ${ }^{3}$ at time $t ;$

${ }^{1}$ SMB stands for small minus big, representing the additional return investors expect, and have historically received, for investing in small capitalization stocks. The factor is as the average return of the smallest $30 \%$ market capitalization stocks minus the average return of the highest $30 \%$ market capitalization stocks. A positive SMB indicates small cap stocks outperformed large cap stocks that period and vice versa.

${ }^{2}$ HML stands for high minus low, representing the premium investors receive for investing in stocks with high book-to-market values. Book value generally is computed as stockholder's equity plus balance sheet deferred taxes and investment tax credit (if applicable) minus book value of preferred stock. Market value is market price per share times shares outstanding. The factor is computed as the average return of the top $50 \%$ of book-to-market stocks minus the average return on the bottom 50\% of book-tomarket stocks. 
The other variables are similar to those in equation (2).

We then replace the HML variable with our "HMLNM" variable in the above two models. The HMLNM variable is constructed similar to the HML variable. Only equity REITs are used and NAV-to-market (NM) is used instead of book-to-market (BM).

$$
\begin{aligned}
& R_{i t}-R_{f t}=\alpha_{0 \mathrm{i}}+\beta_{\mathrm{i}}\left(R_{m t}-R_{f t}\right)+\mathrm{s}_{\mathrm{i}} S M B_{t}+\mathrm{n}_{\mathrm{i}} H M L N M_{t} ; \\
& R_{i t}-R_{f t}=\alpha_{0 \mathrm{i}}+\beta_{\mathrm{i}}\left(R_{m t}-R_{f t}\right)+\mathrm{s}_{\mathrm{i}} S M B_{t}+\mathrm{n}_{\mathrm{i}} H{ } L N M_{t}+\mathrm{m}_{\mathrm{i}} M O M_{t} ;
\end{aligned}
$$

Finally we add our factor to the existing models to see if it adds to the explanatory power of those models:

$R_{i t}-R_{f t}=\alpha_{0 \mathrm{i}}+\beta_{\mathrm{i}}\left(R_{m t}-R_{f t}\right)+\mathrm{s}_{\mathrm{i}} S M B_{t}+\mathrm{h}_{\mathrm{i}} H M L_{t}+\mathrm{n}_{\mathrm{i}} H M L N M_{t} ;$

$R_{i t}-R_{f t}=\alpha_{0 \mathrm{i}}+\beta_{\mathrm{i}}\left(R_{m t}-R_{f t}\right)+\mathrm{s}_{\mathrm{i}} S M B_{t}+\mathrm{h}_{\mathrm{i}} H M L_{t}+\mathrm{n}_{\mathrm{i}} H M L N M_{t}+\mathrm{m}_{\mathrm{i}} M O M_{t} ;$

The model is expanded by substituting $S M B_{t}$ with an equity REIT-based size factor $\left(S M B R_{t}\right)$ then adding $S M B R_{t}$ to equation (6):

$R_{i t}-R_{f t}=\alpha_{0 \mathrm{i}}+\beta_{\mathrm{i}}\left(R_{m t}-R_{f t}\right)+\mathrm{r}_{\mathrm{i}} S M B R_{t}+\mathrm{h}_{\mathrm{i}} H M L_{t}+\mathrm{n}_{\mathrm{i}} H M L N M_{t}+\mathrm{m}_{\mathrm{i}} M O M_{t} ;$

$R_{i t}-R_{f t}=\alpha_{0 \mathrm{i}}+\beta_{\mathrm{i}}\left(R_{m t}-R_{f t}\right)+\mathrm{s}_{\mathrm{i}} S M B_{t}+\mathrm{h}_{\mathrm{i}} H M L_{t}+\mathrm{r}_{\mathrm{i}} S M B R_{t}+\mathrm{n}_{\mathrm{i}} H M L N M_{t}+\mathrm{m}_{\mathrm{i}} M O M_{t} ;$

We add control variables ${ }^{4}$ to equation (8):

$R_{i t}-R_{f t}=\alpha_{0 \mathrm{i}}+\beta_{\mathrm{i}}\left(R_{m t}-R_{f t}\right)+\mathrm{s}_{\mathrm{i}} S M B_{t}+\mathrm{h}_{\mathrm{i}} H M L_{t}+\mathrm{r}_{\mathrm{i}} S M B R_{t}+\mathrm{n}_{\mathrm{i}} H M L N M_{t}+\mathrm{m}_{\mathrm{i}} M O M_{t}+\mathrm{p}_{\mathrm{i}}$ prop $_{t}+\mathrm{r}_{\mathrm{i}}$ wreoc $_{t} ;$

where

$R_{m t}=$ quarterly return of equity REIT index at time $t$

$\operatorname{prop}_{t}=$ quarterly returns of property index at time $t ;$

$w r e o c_{t}=$ quarterly returns of real estate operating companies index at time $t$.

We use the SNL Financial Real Estate Module to extract quarterly data for Price/NAV ratio from third quarter 1992 to fourth quarter 2006 of 122 equity REITs. NAV is calculated based on capitalization rates of the respective time period and REIT sector (industrial, healthcare, hotel/lodging, office, residential, retail). The average capitalization rate for the period is used for diversified REITs, along with REITs in the smaller sectors (storage, theaters, and timber). REIT sector classifications are obtained from NAREIT (National Association of Real Estate Investment Trusts). The NCREIF Property Trends database and Realty.com Investor Survey are the sources of capitalization information. The quarterly equity index returns are obtained from NAREIT. The quarterly property index returns are obtained from NCREIF. The REOC index returns are obtained from Wilshire Real Estate. We use REITs with a minimum eight consecutive quarters of data. We use monthly returns from the CRSP tapes and compound them to produce quarterly returns. Each REIT is classified by its sector of concentration (healthcare, industrial, office, retail, residential, storage, timber and diversified).

\footnotetext{
${ }^{3}$ MOM stands for momentum factor; UMD (up minus down) is also used. This represents the additional return investors expect for investing in stocks with high prior returns. The factor is computed with six value-weight portfolios formed on size and prior (2-12) returns to construct MOM. The portfolios, which are formed monthly, are the intersections of 2 portfolios formed on size (market equity, ME) and 3 portfolios formed on prior (2-12) return. The monthly size breakpoint is the median NYSE market equity. The monthly prior (2-12) return breakpoints are the $30^{\text {th }}$ and $70^{\text {th }}$ NYSE percentiles. MOM is the average return on the two high prior return portfolios minus the average return on the two low prior return portfolios.

${ }^{4}$ Variables representing properties (that REITs could acquire) and REOCs (own income-producing properties but do not operate as REITs) are used to identify any effects from the unique status of REITs.
} 
We obtain variables $R_{f}, \quad S M B_{t}, H M L_{t}$, and $M O M_{t}$ from the Ken French website (http://mba.tuck.dartmouth.edu/pages/faculty/ken.french/data_library.html\#Research). Monthly figures are compounded to produce quarterly returns. Admittedly this method will produce less than accurate SMB, HML, and MOM factors. Monthly equity REIT returns are obtained from the CRSP database and compounded to produce quarterly returns.

\section{RESULTS}

\section{Risk Factor Based On REIT NAV}

\section{Regressions}

We use Table I to show risk factor coefficients based on the Fama and French (1993) three-factor model. The regression is run first in its original form (Panel A), then replacing $H M L_{t}$ with $H M L N M_{t}$ (Panel B), and finally adding $H M L N M_{t}$ to the original model (Panel C). The alpha of 1.97 in Panel A suggests an equity REIT risk premium of $1.97 \%$ unexplained by the model. There is a factor loading on market premium of 0.29 that tells us equity REIT risk is smaller than market risk and can be used as a diversifying asset. There is a factor loading on the size premium of 0.45 and a factor loading on the value premium of 0.44 . All results are significant at the $1 \%$ level. After we replace the value premium with $H M L N M_{t}$, the alpha value of 2.90 increases the level of unexplained risk premium. The factor loading on market premium decreases to $0.19, S M B$ decreases to 0.40 and HMLNM is 0.41 . Adding $H M L N M_{t}$ to the three-factor model produces an alpha of 2.09. The factor loading on the market premium has a value of $0.30, S M B$ has a value of 0.43 and $H M L$ has a value of 0.42 . These values approach those of the original model. In addition, the factor loading on $H M L N M$ has a value of 0.10. An investor who adds high NM REITs to his/her portfolio can only expect a $0.10 \%$ quarterly risk premium. All results are significant at the $1 \%$ level; $H M L N M_{t}$ is significant at the $5 \%$ level.

The relationship between the NAV to Market (NM) risk factor and performance is evaluated with the Fama-French (1992) three-factor model, replacing the HML factor with the HMLNM factor then adding the HMLNM factor to the model :

$R_{i t}-R_{f t}=\alpha_{0 \mathrm{i}}+\beta_{\mathrm{i}}\left(R_{m t}-R_{f t}\right)+\mathrm{s}_{\mathrm{i}} S M B_{t}+\mathrm{h}_{\mathrm{i}} H M L_{t}$;

$R_{i t}-R_{f t}=\alpha_{0 \mathrm{i}}+\beta_{\mathrm{i}}\left(R_{m t}-R_{f t}\right)+\mathrm{s}_{\mathrm{i}} S M B_{t}+\mathrm{n}_{\mathrm{i}} H M L N M_{t}$

$R_{i t}-R_{f t}=\alpha_{0 \mathrm{i}}+\beta_{\mathrm{i}}\left(R_{m t}-R_{f t}\right)+\mathrm{s}_{\mathrm{i}} S M B_{t}+\mathrm{h}_{\mathrm{i}} H M L_{t}+\mathrm{n}_{\mathrm{i}} H M L N M_{t}$;

where $R_{i t}=$ return of REIT $i$ for quarter $t$ (monthly returns from CRSP are compounded), $R_{f t}=$ risk-free rate based on the 30 day T-bill rate, compounded monthly to produce quarterly returns, $R_{m t}=$ return on a market index portfolio for quarter $t, S M B_{t}=$ the average quarterly return of the smallest $30 \%$ of stocks minus the largest $30 \%$ of stocks, $H M L_{t}=$ the average quarterly return of the highest $30 \%$ book-to-market stocks minus the lowest $30 \%$ bookto-market stocks and $H M L N M_{t}=$ the average quarterly return of the highest $30 \%$ NAV-to-market REITs minus the lowest 30\% NAV-to-market REITs. The CRSP NYSE/AMEX/Nasdaq equal-weighted portfolio quarterly returns serve as the market proxy. Panel A looks at the model with HML; Panel B looks at the model with HMLNM, Panel $\mathrm{C}$ looks at HML and HMLNM.

We use Table II to show risk factor coefficients based on the Carhart (1997) four-factor model. The regression is run first in its original form (Panel A), then replacing $H M L_{t}$ with $H M L N M_{t}$ (Panel B). The alpha of 0.87 in Panel A suggests an equity REIT risk premium of $0.87 \%$ unexplained by the model. The addition of the momentum factor removes some of the risk premium unexplained by the model. There is a higher factor loading on market premium (0.43) than the one presented in the Fama and French model. There is a higher factor loading on size premium (0.53) and value premium (0.66). The factor loading on momentum is 0.27 . All results are significant at the $1 \%$ level. After we replace the value premium with $H M L N M_{t}$, the alpha increases to 3.25 . The factor loading on market premium decreases to 0.15 , the factor loading on $S M B$ decreases to $0.37 \%$ and the factor loading on $H M L N M$ is 0.34 . Surprisingly the sign on the momentum factor changes (-0.14). 
Table I: NAV To Market (NM) And Performance; Fama-French Model

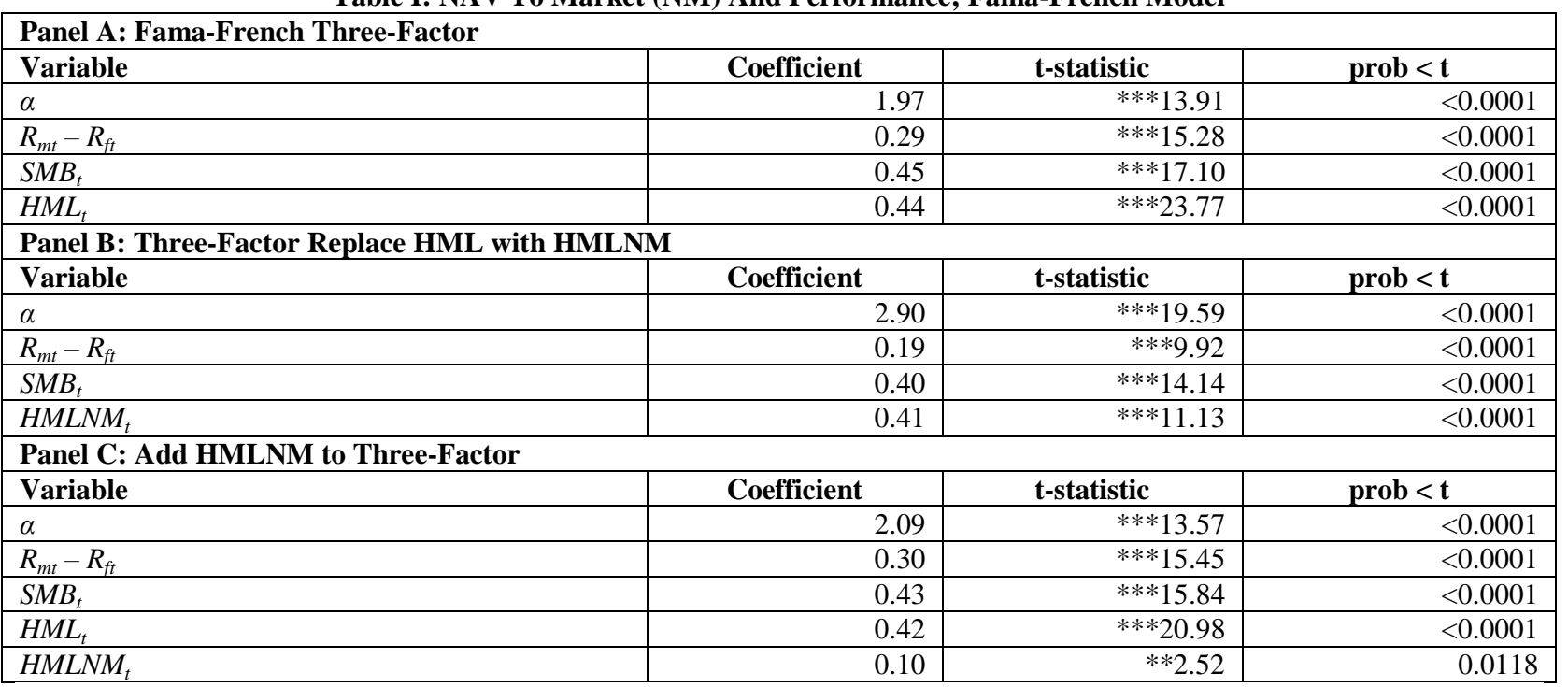

* Significance at $10 \%$ level

**Significance at $5 \%$ level

*** Significance at $1 \%$ level

The relationship between the NAV to Market (NM) risk factor and performance is evaluated with the Carhart (1997) four-factor model, replacing the HML factor with the HMLNM factor:

$R_{i t}-R_{f t}=\alpha_{0 \mathrm{i}}+\beta_{\mathrm{i}}\left(R_{m t}-R_{f t}\right)+\mathrm{s}_{\mathrm{i}} S M B_{t}+\mathrm{h}_{\mathrm{i}} H M L_{t}+\mathrm{m}_{\mathrm{i}} M O M_{t} ;$

$R_{i t}-R_{f t}=\alpha_{0 \mathrm{i}}+\beta_{\mathrm{i}}\left(R_{m t}-R_{f t}\right)+\mathrm{s}_{\mathrm{i}} S M B_{t}+\mathrm{h}_{\mathrm{i}} H M L N M_{t}+\mathrm{m}_{\mathrm{i}} M O M_{t}$;

where $R_{i t}=$ return of REIT $i$ for quarter $t$ (monthly returns from CRSP are compounded), $R_{f t}=$ risk-free rate based on the 30 day T-bill rate, compounded monthly to produce quarterly returns, $R_{m t}=$ return on a market index portfolio for quarter $t, S M B_{t}=$ the average quarterly return of the smallest $30 \%$ of stocks minus the largest $30 \%$ of stocks, $H M L_{t}=$ the average quarterly return of the highest $30 \%$ book-to-market stocks minus the lowest $30 \%$ bookto-market stocks, $M O M_{t}=$ the top 30\% highest prior year return stocks minus the lowest $30 \%$ prior year return stocks and $H_{M L N M}=$ the average quarterly return of the highest 30\% NAV-to-market REITs minus the lowest 30\% NAV-to-market REITs. The CRSP NYSE/AMEX/Nasdaq equal-weighted portfolio quarterly returns serve as the market proxy. Panel A looks at the model with HML; Panel B looks at the model with HMLNM.

We use Table III to show all five risk factor coefficients. Adding $H M L N M_{t}$ to the Carhart model produces an alpha of 0.98 . The factor loading on market premium has a value of 0.43 , the factor loading on $S M B$ has a value of 0.51 , the factor loading on $H M L$ has a value of 0.63 and the factor loading on $M O M$ has a value of 0.27 . These values approach those of the original model. In addition, the factor loading on HMLNM has a value of 0.10 . An investor who adds high NM REITs to his/her portfolio can only expect a $0.10 \%$ risk premium. All values are significant at the $1 \%$ level with the exception of $H M L N M_{t}$ at a $5 \%$ significance level. 
Table II: NAV To Market (NM) And Performance; Four-Factor Model

\begin{tabular}{|c|c|c|c|}
\hline \multicolumn{4}{|c|}{ Panel A: Four-factor with HML } \\
\hline Variable & Coefficient & t-statistic & prob $<\mathbf{t}$ \\
\hline$\alpha$ & 0.87 & $* * * 4.97$ & $<0.0001$ \\
\hline$R_{m t}-R_{f t}$ & 0.43 & $* * * 18.66$ & $<0.0001$ \\
\hline$S M B_{t}$ & 0.53 & $* * * 19.43$ & $<0.0001$ \\
\hline$H M L_{t}$ & 0.65 & $* * * 24.03$ & $<0.0001$ \\
\hline$M_{t}$ & 0.27 & $* * * 10.55$ & $<0.0001$ \\
\hline \multicolumn{4}{|c|}{ Panel B: Four-factor with HMLNM } \\
\hline Variable & Coefficient & t-statistic & prob $<\mathrm{t}$ \\
\hline$\alpha$ & 3.25 & $* * * 20.93$ & $<0.0001$ \\
\hline$R_{m t}-R_{f t}$ & 0.15 & $* * * 7.57$ & $<0.0001$ \\
\hline$S M B_{t}$ & 0.37 & $* * * 13.00$ & $<0.0001$ \\
\hline$H M L N M_{t}$ & 0.34 & $* * * 8.70$ & $<0.0001$ \\
\hline $\mathrm{MOM}_{t}$ & -0.14 & $* * *-7.21$ & $<0.0001$ \\
\hline
\end{tabular}

* Significance at $10 \%$ level

$* *$ Significance at $5 \%$ level

*** Significance at $1 \%$ level

The relationship between the NAV to Market (NM) risk factor and performance is evaluated with the proposed five- factor model:

$R_{i t}-R_{f t}=\alpha_{0 \mathrm{i}}+\beta_{\mathrm{i}}\left(R_{m t}-R_{f t}\right)+\mathrm{s}_{\mathrm{i}} S M B_{t}+\mathrm{h}_{\mathrm{i}} H M L_{t}+\mathrm{m}_{\mathrm{i}} M O M_{t}+\mathrm{n}_{\mathrm{i}} H M L N M_{t} ;$

where $R_{i t}=$ return of REIT $i$ for quarter $t$ (monthly returns from CRSP are compounded), $R_{f t}=$ risk-free rate based on the 30 day T-bill rate, compounded monthly to produce quarterly returns, $R_{m t}=$ return on a market index portfolio for quarter $t, S M B_{t}=$ the average quarterly return of the smallest $30 \%$ of stocks minus the largest $30 \%$ of stocks, $H M L_{t}=$ the average quarterly return of the highest $30 \%$ book-to-market stocks minus the lowest $30 \%$ bookto-market stocks, $M O M_{t}=$ the top $30 \%$ highest prior year return stocks minus the lowest $30 \%$ prior year return stocks and $H M L N M_{t}=$ the average quarterly return of the highest 30\% NAV-to-market REITs minus the lowest $30 \%$ NAV-to-market REITs. The CRSP NYSE/AMEX/Nasdaq equal-weighted portfolio quarterly returns serve as the market proxy.

Table III: NAV To Market (NM) And Performance; Five-Factor Model

\begin{tabular}{|l|r|r|r|}
\hline Variable & Coefficient & t-statistic & prob \\
\hline$\alpha$ & 0.98 & $* t$ & $<* 5.43$ \\
\hline$R_{m t}-R_{f t}$ & 0.43 & $* * * 18.31$ & $<0.0001$ \\
\hline$S M B_{t}$ & 0.51 & $* * * 18.15$ & $<0.0001$ \\
\hline$H M L_{t}$ & 0.63 & $* * * 22.42$ & $<0.0001$ \\
\hline$M O M_{t}$ & 0.27 & $* * * 10.54$ & $<0.0001$ \\
\hline$H M L N M_{t}$ & 0.10 & $* * 2.50$ & $<0.0001$ \\
\hline
\end{tabular}

* Significance at $10 \%$ level

**Significance at $5 \%$ level

*** Significance at $1 \%$ level 


\section{Real Estate Related Controls}

We investigate the effects of factor loadings on the Fama-French and Carhart models when using real estate related factors. We use Table IV to show our changes to the Fama-French model. We replace $S M B_{t}$ with $S M B R_{\mathrm{t}}$ (Panel A) then the $H M L N M_{t}, P R O P_{t}$, and $W R E O C_{t}$ variables are added (Panel B). A look at Panel A finds a factor loading on market premium of 0.28 , a factor loading on $S M B R_{t}$ of 0.47 , and a factor loading on $H M L N M_{t}$ of 1.21. An investor who adds high NM REITs to a market index and equity REIT portfolio could expect a $1.21 \%$ quarterly risk premium. An examination of Panel B finds a loading on $S M B R_{t}$ of 0.30 , smaller than it appears in the original three-factor model. The factor loading on $H M L N M_{t}$ is 0.17 , smaller than the one shown in the original model.

The relationship between the NAV to Market (NM) risk factor and performance is evaluated with a variation of the Fama-French (1992) three factor model, replacing the SMB factor with a REIT-based SMB factor, HML factor with the HMLNM factor and adding real estate related factors to the model :

$R_{i t}-R_{f t}=\alpha_{0 \mathrm{i}}+\beta\left(R_{m t}-R_{f t}\right)+\mathrm{s} S M B R_{t}+\mathrm{n} H M N M L_{t} ;$

$R_{i t}-R_{f t}=\alpha_{0 \mathrm{i}}+\beta\left(R_{m t}-R_{f t}\right)+\mathrm{s} S M B R_{t}+\mathrm{n} H M L N M_{t}+\mathrm{p} P R O P_{t}+\mathrm{c} W R E O C_{t} ;$

where $R_{i t}=$ return of REIT $i$ for quarter $t$ (monthly returns from CRSP are compounded), $R_{f t}=$ risk-free rate based on the 30 day T-bill rate, compounded monthly to produce quarterly returns, $R_{m t}=$ return on a market index portfolio for quarter $t, S M B R_{t}=$ the average quarterly return of the smallest $30 \%$ of equity REITs minus the largest $30 \%$ of equity REITs, $H M L N M_{t}=$ the average quarterly return of the highest $30 \%$ NAV-to-market REITs minus the lowest 30\% NAV-to-market REITs, PROP $_{t}=$ quarterly return of the NCREIF property index, and $W_{R E O C_{t}}=$ quarterly return of the Wilshire Real Estate Operating Companies Index. The CRSP NYSE/AMEX/Nasdaq equalweighted portfolio quarterly returns serve as the market proxy. Panel A looks at the model with SMBR and HMLNM; Panel $\mathrm{B}$ adds PROP and WREOC to the three factor model.

Table IV: NAV To Market (NM) And Performance; Fama-French Model With Real Estate Factors

\begin{tabular}{|c|c|c|c|}
\hline \multicolumn{4}{|c|}{ Panel A: Three Factor with SMBR and HMLNM } \\
\hline Variable & Coefficient & t-statistic & prob $<\mathrm{t}$ \\
\hline$\alpha$ & 3.58 & $* * * 18.68$ & $<0.0001$ \\
\hline$R_{m t}-R_{f t}$ & 0.28 & $* * * 15.63$ & $<0.0001$ \\
\hline$S M B R_{t}$ & 0.47 & $* * * 9.69$ & $<0.0001$ \\
\hline$H M L N M_{t}$ & 1.21 & $* * * 20.88$ & $<0.0001$ \\
\hline \multicolumn{4}{|c|}{ Panel B: Three-factor with RE Factors Added } \\
\hline Variable & Coefficient & t-statistic & prob $<$ t \\
\hline$\alpha$ & 1.35 & $* * 2.33$ & 0.0199 \\
\hline$R_{m t}-R_{f t}$ & 0.05 & $* * 2.11$ & 0.0350 \\
\hline$S M B R_{t}$ & 0.30 & $* * * 5.43$ & $<0.0001$ \\
\hline$H M L N M_{t}$ & 0.17 & $* * * 2.60$ & 0.0094 \\
\hline $\mathrm{PROP}_{t}$ & -0.46 & $* * 2.26$ & 0.0240 \\
\hline$W_{R E O C_{t}}$ & -0.07 & $* *-2.25$ & 0.0244 \\
\hline
\end{tabular}

* Significance at $10 \%$ level

**Significance at $5 \%$ level

*** Significance at $1 \%$ level

Table V is used to show the changes to the Carhart model. $S M B_{t}$ is replaced by $S M B R_{t}$ (Panel A) then the $H M L N M_{t}, P R O P_{t}$, and $W R E O C_{t}$ variables are added (Panel B). A look at Panel A finds a factor loading on market premium of 0.23 , a factor loading on $S M B R_{t}$ of 0.44 , and a factor loading on $H M L N M_{t}$ of 1.01. An investor who adds high NM REITs to a market index and equity REIT portfolio could expect a $1.01 \%$ quarterly risk premium. An examination of Panel B finds a loading on $S M B R_{t}$ of 0.30, smaller than it appears in Panel A. The factor loading on $H M L N M_{t}$ is 0.17 , smaller than the one shown in the original model. 
The relationship between the NAV to Market (NM) risk factor and performance is evaluated with the Carhart (1997) four-factor model, replacing the SMB factor with a REIT-based SMB factor (SMBR), the HML factor with the HMLNM factor and adding real estate related factors to the model:

$R_{i t}-R_{f t}=\alpha_{0 \mathrm{i}}+\beta\left(R_{m t}-R_{f t}\right)+\mathrm{s} S M B R_{t}+\mathrm{n} H M L N M_{t}+\mathrm{m} M O M_{t} ;$

$R_{i t}-R_{f t}=\alpha_{0 i}+\beta\left(R_{m t}-R_{f t}\right)+\mathrm{s} S M B R_{t}+\mathrm{n} H M L N M_{t}+\mathrm{m} M O M_{t}+\mathrm{p} P R O P_{t}+\mathrm{c} W_{R E O C_{t}}$;

where $R_{i t}=$ return of REIT $i$ for quarter $t$ (monthly returns from CRSP are compounded), $R_{f t}=$ risk-free rate based on the 30 day T-bill rate, compounded monthly to produce quarterly returns, $R_{m t}=$ return on a market index portfolio for quarter $t, S M B R_{t}=$ the average quarterly return of the smallest $30 \%$ of equity REITs minus the largest $30 \%$ of equity REITs, $H M L N M_{t}=$ the average quarterly return of the highest $30 \%$ NAV-to-market REITs minus the lowest 30\% NAV-to-market REITs, $M O M_{t}=$ the top 30\% highest prior year return stocks minus the lowest $30 \%$ prior year return stocks, $P R O P_{t}=$ quarterly return of the NCREIF property index, and $W R E O C_{t}=$ quarterly return of the Wilshire Real Estate Operating Companies Index. The CRSP NYSE/AMEX/Nasdaq equal-weighted portfolio quarterly returns serve as the market proxy. Panel A looks at the model with SMBR and HMLNM; Panel B adds $P R O P$ and WREOC to the three factor model.

Table V: NAV to Market (NM) And Performance; Carhart Model With Real Estate Factors

\begin{tabular}{|c|c|c|c|}
\hline \multicolumn{4}{|c|}{ Panel A: Four Factor with SMBR and HMLNM } \\
\hline Variable & Coefficient & t-statistic & prob $<\mathbf{t}$ \\
\hline$\alpha$ & 3.74 & $* * * 19.36$ & $<0.0001$ \\
\hline$R_{m t}-R_{f t}$ & 0.23 & $* * * 11.16$ & $<0.0001$ \\
\hline$S M B R_{t}$ & 0.44 & $* * * 9.05$ & $<0.0001$ \\
\hline$H M L N M_{t}$ & 1.01 & $* * * 14.79$ & $<0.0001$ \\
\hline $\mathrm{MOM}_{t}$ & -0.12 & $* * *-5.47$ & $<0.0001$ \\
\hline \multicolumn{4}{|c|}{ Panel B: Four Factor with RE Factors Added } \\
\hline Variable & Coefficient & t-statistic & prob $<\mathbf{t}$ \\
\hline$\alpha$ & 1.39 & $* * 2.39$ & 0.0167 \\
\hline$R_{m t}-R_{f t}$ & 0.04 & 1.62 & 0.1051 \\
\hline$S M B R_{t}$ & 0.29 & $* * * 5.38$ & $<0.0001$ \\
\hline$H M L N M_{t}$ & 0.07 & 0.96 & 0.3396 \\
\hline $\mathrm{MOM}_{t}$ & -0.08 & $* * *-3.67$ & $<0.0001$ \\
\hline $\mathrm{PROP}_{t}$ & -0.43 & $* *-2.10$ & 0.0355 \\
\hline$W_{R E O C_{t}}$ & -0.12 & $* * *-3.49$ & 0.0005 \\
\hline
\end{tabular}

* Significance at $10 \%$ level

**Significance at $5 \%$ level

*** Significance at $1 \%$ level

The results of a multi-factor model are shown in Table VI. $S M B R_{t}$ and $H M L N M_{t}$ are added to isolate the REIT-related size and value factors; the $H M L N M_{t}, P R O P_{t}$, and $W R E O C_{t}$ variables are added as real estate related controls. A look at Panel A finds a factor loading on market premium of 0.08 (CRSP EW portfolio is the market proxy), a factor loading on $S M B_{t}$ of 0.14 , a factor loading on $H M L_{t}$ of 0.11 , and a factor loading on $S M B R_{t}$ of 0.22 . An investor who adds small size REITs to a market index and equity REIT portfolio could expect a $0.22 \%$ quarterly risk premium. No significant results are found on the value NM factor. An examination of Panel B finds a factor loading on market premium of 0.84 (FTSE equity REIT index is the market proxy), a factor loading on $S M B_{t}$ of 0.12 , a factor loading on $H M L_{t}$ of 0.05 , and a factor loading on $S M B R_{t}$ of 0.16 . An investor who adds small size REITs to a market index and equity REIT portfolio could expect a $0.16 \%$ quarterly risk premium. No significant results are found on the value NM factor. The results in Panel C (Wilshire REIT index is the market proxy) and Panel D (Russell 2000 index is the market proxy) show similar results. 
The relationship between the NAV to Market (NM) risk factor and performance is evaluated with the proposed multi-factor model:

$R_{i t}-R_{f t}=\alpha_{0 \mathrm{i}}+\beta\left(R_{m t}-R_{f t}\right)+\mathrm{s} S M B_{t}+\mathrm{h} H M L_{t}+\mathrm{m} M O M_{t}+\mathrm{r} S M B R_{t}+\mathrm{n} H M L N M_{t}+\mathrm{p} P R O P_{t}+\mathrm{c} W R E O C_{t} ;$

where $R_{i t}=$ return of REIT $i$ for quarter $t$ (monthly returns from CRSP are compounded), $R_{f t}=$ risk-free rate based on the 30 day T-bill rate, compounded monthly to produce quarterly returns, $R_{m t}=$ return on a market index portfolio for quarter $t, S M B_{t}=$ the average quarterly return of the smallest $30 \%$ of stocks minus the largest $30 \%$ of stocks, $H M L_{t}=$ the average quarterly return of the highest $30 \%$ book-to-market stocks minus the lowest $30 \%$ bookto-market stocks, $M O M_{t}=$ the top 30\% highest prior year return stocks minus the lowest $30 \%$ prior year return stocks, $S M B R_{t}=$ the average quarterly return of the smallest $30 \%$ of equity REITs minus the largest $30 \%$ of equity REITs, $H M L N M_{t}=$ the average quarterly return of the highest $30 \%$ NAV-to-market REITs minus the lowest $30 \%$ NAV-to-market REITs, $P R O P_{t}=$ quarterly return of the NCREIF property index, and $W_{R E O C}=$ quarterly return of the Wilshire Real Estate Operating Companies Index. Panel A looks at the model with the CRSP NYSE/AMEX/Nasdaq equal-weighted portfolio quarterly returns as the market proxy. Panel B looks at the model with the NAREIT equity REIT quarterly returns as the market proxy. Panel C looks at the model with the Wilshire REIT quarterly returns as the market proxy. Panel D looks at the model with the Russell 2000 quarterly returns as the market proxy.

Table VI: NAV To Market (NM) And Performance; Multi-Factor Model

\begin{tabular}{|c|c|c|c|}
\hline \multicolumn{4}{|c|}{ Panel A: CRSP EW Portfolio as Market Proxy } \\
\hline Variable & Coefficient & t-statistic & prob $<\mathrm{t}$ \\
\hline$\alpha$ & 0.44 & 0.62 & 0.5343 \\
\hline$R_{m t}-R_{f t}$ & 0.08 & $* * 2.16$ & 0.0307 \\
\hline$S M B_{t}$ & 0.14 & $* * * 3.03$ & 0.0025 \\
\hline$H M L_{t}$ & 0.11 & $* * * 2.71$ & 0.0067 \\
\hline $\mathrm{MOM}_{t}$ & -0.01 & -0.12 & 0.9052 \\
\hline$S M B R_{t}$ & 0.22 & $* * * 3.79$ & 0.0002 \\
\hline$H M L N M_{t}$ & 0.05 & 0.71 & 0.4803 \\
\hline $\mathrm{PROP}_{t}$ & -0.16 & -0.62 & 0.5321 \\
\hline$W R E O C_{t}$ & -0.10 & $* * *-2.95$ & 0.0032 \\
\hline \multicolumn{4}{|c|}{ Panel B: NAREIT Equity REIT Index as Market Proxy } \\
\hline Variable & Coefficient & t-statistic & prob $<$ t \\
\hline$\alpha$ & 0.32 & 0.47 & 0.6417 \\
\hline$R_{m t}-R_{f t}$ & 0.84 & $* * * 2.86$ & 0.0043 \\
\hline$S M B_{t}$ & 0.12 & $* * * 2.84$ & 0.0045 \\
\hline$H M L_{t}$ & 0.05 & $* 1.69$ & 0.0918 \\
\hline$M O M_{t}$ & -0.03 & -0.99 & 0.3244 \\
\hline$S M B R_{t}$ & 0.16 & $* * 2.44$ & 0.0148 \\
\hline$H_{M L N M_{t}}$ & 0.01 & 0.09 & 0.9286 \\
\hline $\mathrm{PROP}_{t}$ & 0.21 & 0.88 & 0.3785 \\
\hline$W_{R E O C_{t}}$ & 0.01 & 0.24 & 0.8074 \\
\hline
\end{tabular}

* Significance at $10 \%$ level

**Significance at $5 \%$ level

*** Significance at $1 \%$ level 
Table VI: NAV To Market (NM) And Performance; Multi-Factor Model (Continued)

\begin{tabular}{|c|c|c|c|}
\hline \multicolumn{4}{|c|}{ Panel C: Wilshire REIT Index as Market Proxy } \\
\hline Variable & Coefficient & t-statistic & prob $<\mathrm{t}$ \\
\hline$\alpha$ & 0.05 & 0.07 & $<0.0001$ \\
\hline$R_{m t}-R_{f t}$ & 1.04 & $* * 2.34$ & 0.0191 \\
\hline$S M B_{t}$ & 0.15 & $* * * 3.50$ & 0.0005 \\
\hline$H M L_{t}$ & 0.07 & $* * 2.23$ & 0.0257 \\
\hline$M O M_{t}$ & -0.04 & -1.33 & 0.1840 \\
\hline$S M B R_{t}$ & 0.25 & $* * * 4.41$ & $<0.0001$ \\
\hline$H M L N M_{t}$ & -0.02 & -0.34 & 0.7361 \\
\hline $\mathrm{PROP}_{t}$ & 0.35 & 1.27 & 0.2026 \\
\hline$W_{R E O C_{t}}$ & 0.03 & 0.47 & 0.6361 \\
\hline \multicolumn{4}{|c|}{ Panel D: Russell 2000 Index as Market Proxy } \\
\hline Variable & Coefficient & t-statistic & prob $<$ t \\
\hline$\alpha$ & 0.68 & 0.89 & 0.3725 \\
\hline$R_{m t}-R_{f t}$ & 0.08 & $* 1.95$ & 0.0513 \\
\hline$S M B_{t}$ & 0.07 & 1.35 & 0.1787 \\
\hline$H M L_{t}$ & 0.09 & $* * 2.49$ & 0.0130 \\
\hline$M O M_{t}$ & -0.02 & -0.45 & 0.6506 \\
\hline$S M B R_{t}$ & 0.23 & $* * * 4.08$ & $<0.0001$ \\
\hline$H M L N M_{t}$ & -0.05 & 0.63 & 0.5277 \\
\hline $\mathrm{PROP}_{t}$ & -0.23 & -0.85 & 0.3964 \\
\hline $\mathrm{WREOC}_{t}$ & -0.10 & $* * *-2.92$ & 0.0035 \\
\hline
\end{tabular}

* Significance at $10 \%$ level

**Significance at $5 \%$ level

*** Significance at $1 \%$ level

\section{CONCLUSIONS}

REIT NAV is the basis for determining REIT discount. This in turn presents a NAV to market price ratio that is used in the Fama and French (1993) and Carhart (1997) asset pricing models. Substitution of the HML factor with the HMLNM factor reduces beta and the size premium while increasing alpha in the three-factor model. Adding HMLNM to the three-factor model produces coefficients similar to the original model while adding a $0.10 \%$ change to the REIT risk premium. Substitution of the HML factor with the HMLNM factor reduces beta and the size premium. The substitution also reverses the sign on the momentum factor while increasing alpha in the fourfactor model. Adding HMLNM to the four-factor model produces coefficients similar to the original model while adding a $0.10 \%$ change to the REIT risk premium. The HMLNM factor adds minimal effects to the model as presented in this paper. Adding additional controls (term and default factors to name two) will be pursued in future work.

\section{ABOUT THE AUTHORS}

Dr. Bill Brent, DBA, is an Associate Professor of Finance in the Department of Finance, International Business and Real Estate at Howard University. On active duty he has served as Controller, Naval Hospital Quantico, Virginia and National Naval Medical Center, Bethesda, MD. He has additionally been Financial Planner for Blue Cross/Shield and Financial Systems Coordinator for at Georgetown University Hospital. His research efforts have focused on M\&A Case Analysis, and Capital Structure analysis as Associate Editor, Journal of Financial Case Research; foreclosures, financial literacy as Principal Investigator for the Howard University's research efforts.

Dr. Lynne Kelly is an Assistant Professor in the Department of Finance, International Business and Insurance at Howard University in Washington, DC. She conducts research in the areas of real estate, international finance, and mutual fund performance.

Debby Lindsey-Taliefero, Ph.D. is an Associate Professor of Economics in the Department of Finance at Howard University. Her research efforts have focused on mortgage lending, foreclosures, financial literacy, and 
discrimination in auto financing. Her work has been featured or cited by ABC 20/20, New York Times, Washington Post, and in a DOJ's Amicus brief- auto finance litigation. Prior to Howard, she worked as an economist for ComplianceTech, Anser; the Federal Emergency Management Agency; the National Urban League, and the NAACP

Russell M. Price, Ph.D. joined the Howard University faculty in Fall 2006. He teaches courses in Macroeconomics, Financial Management, Finance Principles, Financial Modeling, Financial Markets/Institutions and Commercial Real Estate/Housing Finance. He also serves as a faculty advisor of the Howard University Real Estate Club. He holds a B.S. in Civil Engineering from Cornell University in Ithaca, NY and a Ph.D. in Finance from The Florida State University in Tallahassee, FL. His research interests include real estate finance, asset pricing, valuation, mutual funds, mortgage pricing and REITs. His research appears in the Journal of Real Estate Research, Journal of Business and Economic Research, Journal of the Academy of Economics and Finance and Journal of Real Estate Portfolio Management.

\section{REFERENCES}

1. Carhart, Mark M., (1997), On Persistence in Mutual Fund Performance, Journal of Finance, 52 (1), 57-82.

2. Chaudhry, Mukesh K., S. Maheshwari and J. R. Webb (2004), REITs and Idiosyncratic Risk, Journal of Real Estate Research, 26(2), 207-222.

3. Elton, Edwin J., M. Gruber and J. Blake (1998), Do Investors Care About Sentiment?, Journal of Business, 71(4), 477-500.

4. Fama, Eugene and K. French (1993), Common Risk Factors in the Returns of Stocks and Bonds, Journal of Financial Economics 33(1), 3-53.

5. Lee, Charles M. C., A. Shleifer and R. H. Thaler (1991), Investor Sentiment and the Closed-End Fund Puzzle, Journal of Finance, 46(1), 75-109.

6. Liang, Youguo, W. McIntosh and J.R. Webb (1995), Intertemporal Changes and the Riskiness of REITs, Journal of Real Estate Research, 10(4), 427-443.

7. Lin, Yi (2004), REIT Risk Premium: The Effects of Investor Sentiment and Institutional Ownership; Essay 3 of dissertation, Old Dominion University.

8. Liow, Kim Hiang, (2003), Property Company Stock Price and Net Asset Value: A Mean Reversion Perspective, Journal of Real Estate and Financial Economics, 27 (2), 235-255.

9. Liow, Kim Hiang ad Y. Li (2006), Net Asset Value Discount for Asian-Pacific Real Estate Companies: Long-Run Relationships and Short Term Dynamics, Journal of Real Estate and Financial Economics, 33(4), 363-388.

10. Miller, Merton, N. Chen and R. Kan (1993a), Are the Discounts on Closed-End Funds a Sentiment Index? Journal of Finance 48(2), 795-800.

11. Miller, Merton, N. Chen and R. Kan (1993b), Yes, Discounts on Closed-End Funds are a Sentiment Index: A Rejoinder, Journal of Finance 48(2), 809-810.

12. Neal, Robert and S.M. Wheatley (1998), Do Measures of Investor Sentiment Predict Returns?, Journal of Financial and Quantitative Analysis, 33(4), 523-547.

13. Peterson, J.D. and C. Hseih (1997), Do Common Risk Factors in the Returns of Stocks and Bonds Explain Returns on REITs?, Real Estate Economics, 25(2), 321-345.

14. Swaminathan, Bhaskaran (1996), Time-Varying Expected Small Firm Returns and Closed-End Fund Discounts, Review of Financial Studies, 9(3), 845-887. 
NOTES 